\title{
Penggunaan ekstrak semanggi air (Marsilea crenata) sebagai sumber fitoestrogen terhadap gambaran darah tikus (Rattus norvegicus)
}

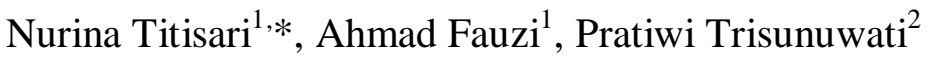 \\ ${ }^{1}$ Fakultas Kedokteran Hewan, Universitas Brawijaya, Malang, Indonesia \\ ${ }^{2}$ Fakultas Peternakan, Universitas Brawijaya, Malang, Indonesia
}

\begin{abstract}
ABSTRAK: Tanaman semanggi air mengandung fitoestrogen yang mungkin dapat berpengaruh terhadap profil darah. Tujuan dari penelitian ini adalah untuk melihat gambaran darah pada tikus betina setelah pemberian semanggi air. Tikus betina (Rattus norwegicus) sebanyak 30 ekor dalam penelitian ini dibagi menjadi 6 kelompok yaitu: I (K-) kontrol negatif, II (K+) kontrol positif, III (P1) diberi ekstrak semanggi air 6.25\%, IV (P2) diberi ekstrak semanggi air 12.5\%, V (P3) diberi ekstrak semanggi air 25\% dan VI (P4) diberi ekstrak semanggi air 50\%. Ekstrak etanol semanggi air diberikan peroral selama 21 hari pascapenyerentakkan berahi menggunakan prostaglandin 2 alfa dua hari sebelumnya. Profil darah lengkap diperiksa sesudah perlakuanpada parameter white blood cell (WBC), red blood cell (RBC), hemoglobin ( $\mathrm{Hb})$ dan packed cell volume (PCV). Hasil analisa menunjukkan bahwa WBC, RBC, Hb dan PCV pada darah tikus menunjukkan perbedaan yang tidak signifikan diantara kelompok perlakuan. Kesimpulan dari penelitian ini yaitu pemberian ekstrak semanggi tidak mempengaruhi profil hematologi tikus.
\end{abstract}

Kata kunci:

semanggi air, WBC, RBC, Hb, PCV

\section{- PENDAHULUAN}

Fitoestrogen adalah substrat tumbuhan yang memiliki aktivitas menyerupai estrogen, meskipun struktur kimia keduanya berbeda (Glover \& Assinder 2006). Salah satu senyawa kimia yang termasuk fitoestrogen adalah isoflavone. Isoflavone merupakan compound-like hormone yang terdapat pada berbagai tanaman seperti pada tanaman semanggi air. Isoflavone yang dimiliki semanggi air dapat meniru peran hormon estrogen pada tubuh wanita. Mengkonsumsi semanggi air dilaporkan mampu meningkatkan kadar estrogen dalam darah (Anisah 2008), namun pengaruh mengkonsumsi semanggi air terhadap gambaran darah belum dilaporkan. Menurut Prossnitz et al. (2007), estrogen berperan sebagai anti-inflammatory dan membantu mobilisasi sel darah putih. Dengan demikian, pengukuran konsentrasi ekstrak dalam pemberian semanggi air sangat diperlukan untuk mengetahui pengaruhnya terhadap profil hematologi. Penelitian ini bertujuan untuk melihat profil darah tikus setelah pemberian ekstrak etanol daun semanggi air untuk mengetahui keamanan mengkonsumsi semanggi air terus menerus.

\section{- BAHAN DAN METODE}

Pembuatan ekstrak etanol daun semanggi air: Pembuatan ektrak daun semanggi air dilakukan di Materia Medica kota Batu Malang menggunakan etanol $96 \%$.

Hewan coba: Tikus (Rattus norvegicus) betina, strain Wistar, usia 8 minggu, berat badan rata-rata 200 gram. Hewan coba diaklimatisasi selama 7 hari, diberi pakan dan minum tersedia secara ad libitum. Tikusdiperoleh dari Laboratorium Biomol, FMIPA Universitas Brawijaya. Pemeliharaan di Laboratorium Faal, Fakultas Kedokteran, Universitas Brawijaya. Penelitian ini mendapatkan laik etik penelitian dari Universitas Brawijaya No. 347/EC/KEPK/ 05/2015. Hewan coba dibagi dalam 6 kelompok: 4 kelompok perlakuan dengan dosis ekstrak etanol daun semanggi air $(6.25 \%, 12.5 \%, 25 \%$, dan $50 \%)$ dan 2 kelompok kontrol (kontrol negatif diberikan larutan fisiologis dan kontrol positif diberikan Mycrogynon).

Pemberian estrak etanol daun semanggi air: Semua tikus diberikan Prostaglandin F2 $\alpha$ (PGF2 $\alpha$ ) untuk penyerentakan birahi 2 hari sebelum perlakuan. Tikus diberi ekstrak etanol semanggi air sebanyak 2 cc setiap pagi selama 21 hari menggunakan sonde lambung.

Pemeriksaan darah: Darah dikoleksi melalui kapiler orbital kemudian dimasukkan ke tabung yang mengandung EDTA. Profil darah yang diamati meliputi jumlah white blood cell (WBC), red blood cell (RBC), hemoglobin (Hb), dan packed cell volume (PCV).

Analisis data: Hasil pemeriksaan darah dianalisa menggunakan analisis of varian (ANOVA). Uji dilanjutkan dengan perbandingan berganda uji Tukey atau Beda Nyata Jujur (BNJ) dengan $\alpha=0.05$.

Diterima: 29-01-2019 | Direvisi: 21-02-2019 | Disetujui: 26-02-2019

(C) 2019 CC-BY-SA. Ini adalah artikel Open Access yang didistribusikan berdasarkan ketentuan dari Creative Commons Attribution ShareAlike 4.0 International License (https://creativecommons.org/licenses/by-sa/4.0/). 
Tabel 1 Hasil pemeriksaan white blood cells (WBC), red blood cells (RBC), hemoglobin (Hb), dan packed cell volume (PCV) dalam darah tikus setelah 21 hari pemberian ekstrak etanol semanggi air secara berturut-turut.

\begin{tabular}{|c|c|c|c|c|}
\hline Perlakuan & WBC $\left(10^{3} / \mu \mathrm{l}\right)$ & $\operatorname{RBC}\left(10^{6} / \mu \mathrm{l}\right)$ & Hb (g/dl) & PCV (\%) \\
\hline K- (Kontrol Negatif) & $2.50 \pm 0.36$ & $7.42 \pm 0.15$ & $17.02 \pm 0.44$ & $43.47 \pm 1.95$ \\
\hline K+ (Kontrol Positif) & $3.43 \pm 1.59$ & $6.88 \pm 0.07$ & $15.93 \pm 1.31$ & $39.53 \pm 3.09$ \\
\hline P1 (Extrak semanggi $6.25 \%$ ) & $4.60 \pm 0.30$ & $7.28 \pm 0.49$ & $16.97 \pm 1.00$ & $43.17 \pm 2.80$ \\
\hline P2 (Extrak semanggi $12.5 \%$ ) & $3.13 \pm 0.59$ & $7.00 \pm 0.15$ & $16.07 \pm 0.21$ & $42.10 \pm 1.18$ \\
\hline P3 (Extrak semanggi 25\%) & $6.77 \pm 2.61$ & $7.15 \pm 0.26$ & $16.57 \pm 1.00$ & $41.17 \pm 3.41$ \\
\hline P4 (Extrak semanggi 50\%) & $6.33 \pm 2.96$ & $7.04 \pm 0.25$ & $16.53 \pm 0.60$ & $41.87 \pm 3.46$ \\
\hline Nilai P & 0.060 & 0.200 & 0.450 & 0.570 \\
\hline
\end{tabular}

\section{- HASIL DAN PEMBAHASAN}

\section{Nilai WBC}

Pemeriksaan white blood cells (WBC) pada penelitian ini dilakukan untuk melihat respon sistemik terhadap peningkatan leukosit atau sebaliknya. Nilai WBC pada kelompok perlakuan ekstrak semanggi air mengalami peningkatan dibandingkan dengan kelompok kontrol negatif, terutama nilai WBC pada kelompok perlakuan P3 dan P4 yakni 6.77 x $10^{3} / \mu 1$ dan $6,33 \times 10^{3} / \mu 1$ (Tabel 1). Peningkatan nilai WBC pada kelompok perlakuan P3 dan P4 dapat dipengaruhi oleh pemberian ekstrak etanol semanggi air. Fitoestrogen dalam ekstrak etanol semanggi air mampu memobilisasi sel darah putih sehingga meningkatkan nilai WBC dalam darah. Menurut Anisah (2008), pemberian semanggi air dosis $30 \mathrm{mg} / \mathrm{kg}$ berat badan dapat meningkatkan kadar estrogen darah pada tikus betina. Namun demikian nilai ratarata WBC pada setiap kelompok perlakuan masih dalam batas normal. Menurut Schalm (2010) nilai normal sel darah putih pada tikus Wistar yakni $1.96-8.25\left(10^{3} / \mathrm{mm}^{3}\right)$.

\section{Nilai RBC, Hb dan PCV}

Analisa red blood cells, hemoglobin, dan packed cell volume adalah salah satu metode untuk mengetahui status fisiologi hewan terutama yang berkaitan dengan kondisi anemia. Kondisi anemia dapat terjadi pada beberapa penyakit seperti talasemia, anemia aplastic, malnutrisi, trauma dan perdarahan akut atau kronis (Salasia \& Hariono 2014). Nilai rata-rata RBC tikus pada kelompok kontrol dan perlakuan masih berada pada rata-rata normal 7.3-9.6 $\left(10^{6} / \mathrm{mm}^{3}\right)$ (Schalm 2010). Total RBC secara statistik menunjukkan tidak adanya perbedaan diantara kelompok perlakuan (p>0.05) (Tabel 1). Hal ini menunjukkan bahwa pemberian ekstrak etanol semanggi air pada tikus dengan konsentrasi $(6.25 \%, 12.5 \%, 25 \%$, dan 50\%) sebagai fitoestrogen tidak berpengaruh terhadap jumlah eritrosit dalam darah.

Nilai rata-rata $\mathrm{Hb}$ pada kelompok kontrol dan perlakuan menunjukkan kadar masih dalam batas normal. Menurut Schalm (2010), kadar Hb darah tikus normal adalah 13.717.6 (g/dL). Hemoglobin mempunyai peranan membawa oksigen dari paru-paru keseluruh tubuh melalui sel eritrosit. Hasil uji statistik menunjukkan tidak ada perbedaan antar perlakuan. Hal ini menunjukkan bahwa ekstrak etanol semanggi air juga tidak memberikan efek yang berarti terhadap kadar $\mathrm{Hb}$ dalam darah.
Packed cell volume (PCV) atau nilai hematokrit merupakan persentase volume eritrosit di dalam darah. Tujuan pemeriksaan PCV adalah untuk mengetahui konsentrasi sel darah dalam cairan darah. Hasil pemeriksaan PCV pada kelompok perlakuan pemberian ekstrak etanol semanggi air menunjukkan hasil yang tidak berbeda jauh dengan kelompok kontrol negatif. Nilai PCV pada kelompok pemberian ekstrak semanggi air berada pada kisaran nilai normal PCV tikus yakni 39.6-52.5\% (Schalm 2010). Hasil uji statistik menunjukkan bahwa tidak terdapat perbedaan jumlah PCV diantara kelompok perlakuan. Hal ini menunjukkan bahwa pemberian ekstrak semanggi air pada hewan coba tidak berpengaruh terhadap kadar PCV dalam darah. Penurunan PCV dapat terjadi pada kasus perdarahan akut, akibat keracunan atau trauma, anemia, leukemia, gagal ginjal kronis, sirosis hepatitis, defesisensi vitamin B dan C dan malnutrisi (Salasia \& Hariono 2014).

\section{- SIMPULAN}

Ekstrak semanggi tidak berpengaruh terhadap gambaran profil darah tikus pada parameter WBC, RBC, Hb dan PCV.

\section{- INFORMASI PENULIS}

\section{Penulis untuk Korespondensi}

*NT: nurinatitisari@gmail.com

Fakultas Kedokteran Hewan Kampus II, Universitas Brawijaya, Perum Puncak Dieng Ekslusive, Malang.

\section{- PUSTAKA ACUAN}

Anisah K. 2008. Pengaruh pemberian ekstrak daun semanggi air (Marsilea crenata) terhadap kadar estrogen dalam darah tikus putih betina (Rattus norvegicus). Repositori thesis Universitas Airlangga, Surabaya.

Glover A, Assinder SJ. 2006. Acute exposure of adult male rats to dietary phytoestrogen reduces fecundity and alters epididymal steroid hormon receptor expression. Jour. Endoc. 189: 565-573

Prossnitz ER, Arterburn JB, Sklar LA. 2007. GPR30: A G proteincoupled receptor for estrogen. Mol. Cell. Endocrinol. 265:138142.

Salasia SIO, Hariono B. 2014. Patologi Klinik Veteriner: Kasus Patologi Klinis. Penerbit Samudra Biru, Yogyakarta. Halaman 14, 9, 33-41.

Schalm OW. 2010. Veterinary Hematology. Edisi ke-6. Lea \& Febiger, Philadelphia. 